\title{
Implementation of PMSE VAT in Indonesia: Implementation and Challenges
}

\author{
Arif Kurniawan *, Dandis * \\ * Graduate Student, Institut STIAMI Jakarta \\ DOI: 10.29322/IJSRP.11.07.2021.p11572 \\ http://dx.doi.org/10.29322/IJSRP.11.07.2021.p11572
}

\begin{abstract}
The development of the digital economy continues to expand to all lines of business and government. The digital economy is currently spearheading economic growth in all countries. As a follow-up to the digital economy phenomenon, tax regulations that regulate digital transactions are needs. The current tax regulations are the first steps taken by the government. There are several challenges and obstacles in the imposition of digital taxes, but the government must carefully formulate regulations so that the potential for digital taxes can increase state revenue
\end{abstract}

Index Terms - VAT, digital tax, PMSE

\section{Background Issues}

The development of today's digital economy can found in everyday life. Information and communication technology has recently driven in carrying out economic activities. The public chose the digitization of the economy because it is more practical and efficient. The condition Covid-19 Pandemic also accelerates the development of the digital economy where one must reduce crowds and perform all their activities from their respective places.

The development of the digital economy continues to grow across all lines of business and government. The digitization of the economy can inevitably improve the economy. The digital economy is now spearheading economic development in all countries. The application of digitalization of the economy developed as the industrial era 4.0. In industrial era 4.0, electronic trading practices automatically have an impact on the tax aspect. Several large digital companies have cross-border businesses in Indonesia, including Google, Amazon, Facebook, Twitter, Netflix, Spotify, and Instagram.

As a follow-up to the digital economy phenomenon, taxation rules give as govern digital transactions. The taxation rules create equality of taxation treatment (level playing field) between conventional businesses and digital economy businesses. as well as between digital economy businesses at home and abroad, providing legal certainty to collect VAT on the utilization of Intangible BKP and or JKP from outside the Customs Area inside the Customs Territory through Electronic System Trade (PMSE) and optimization of tax receipts. The taxation rules need to capture the potential of e-commerce taxation that develops in Indonesia. Implementing the regulations to capture digital economic activities is issuing Government Regulation No. 80 of 2019 on Trade through Electronic Systems (PMSE). The Government regulation explains that sellers in online stores or $e$-commerce are required to have a business license. This rule also applies to overseas businesses that actively trade through electronic systems (PMSE) to consumers in Indonesia.

As the initial stage of applying taxation in PMSE activities in Indonesia, issued Regulation of the Minister of Finance (PMK) No. 48/PMK.03/2020 concerning Procedures for Appointment of Collectors, Collection, and Deposit, and Value Added Tax Reporting on The Utilization of Intangible Taxable Goods and or Taxable Services from Outside the Customs Territory in the Customs Territory through Trade through Electronic System. The rule stipulates that PMSE businesses, consisting of foreign traders, foreign service providers, overseas PMSE (PPMSE) operators, and domestic PPMSE, are appointed to collect, deposit, and report value-added tax (VAT). On the utilization of intangible taxable goods and or taxable services outside the customs territory within the customs territory through PMSE. VAT on this PMSE will be effective from July 1, 2020. 
Directorate General of Taxes (DGT) stated that the implementation of Value Added Tax (PPN) on trading through electronic systems (PMSE) is the first step, and there are still challenges that must be answered or anticipated. Implementing VAT imposition in PMSE is still not optimal if it looks at comparisons with other countries. Until the end of 2020, the number of overseas companies designated as PMSE VAT collectors in Indonesia is forty-six. This number is tiny compared to other countries. For example, Australia has established approximately 560 companies since 2017.

\section{Theoretical Foundation}

Following Article 4 paragraph (2) PERPU 1/2020, Electronic System Trading (PMSE) is a trade whose transactions organize through a series of electronic devices and procedures. Article 4 paragraph (1) PP No. 80/2019 explains the parties that can do PMSE, including businesses, consumers, personal, and state organizing agencies. The parties conducting PMSE activities can consist of domestic and foreign enterprises.

In other rules, following Article 7 paragraph (1) PP No.80/2019 states that overseas PMSE businesses that actively make offers to consumers in Indonesia can be considered to meet physical presence or set a permanent establishment (BUT) if they meet specific criteria.

Specific criteria that can give as the basis for establishing PMSE as BUT can be in the form of the number of transactions, the value of commerce, the number of delivery packages, and or the amount of traffic or accesses stipulated in The Directorate General of Taxation Regulation No. 12 of 2020.

Businesses through PMSE can conduct their business through means created and managed directly by their companies or through the means owned by the Electronic System Trading Operator (PPMSE). Understanding of Electronic System Trading Operators (PPMSE) following Article 6 paragraph (4) jo. Article 1 PP 80/2019 is a business provider of electronic communication facilities used for trade transactions. Parties that become PPMSE can also come from within the country or abroad.

Through the tax authority in the country, the government can designate PMSE and PPMSE from abroad as a form of permanent business (BUT) if it meets the requirements of significant economic presence.

Under the rules in Article 6 paragraph (7) PERPU 1/2020, there are three provisions of significant economic presence that can determine as a reference for the determination of BUT are as follows:

1. Gross circulation of consolidated business groups up to a certain amount

2. Sales in Indonesia up to a certain amount

3. Active users of digital media in Indonesia up to a certain number

The Implementation Rules for implementing Electronic System Value Added Tax (PMSE) marking by issuing Regulation of the Minister of Finance No. 48/PMK.03/2020. Through the Directorate General of Taxation (DGT), the government began collecting Value Added Tax (PPN) from overseas companies on digital imports starting July 1, 2020, with a VAT amount of 10\% from the Tax Base. The principle of imposition of VAT on Taxable Goods/Services in Indonesia is the destination principle,i.e., tax is imposing at the destination of goods/services consumed. With the above rules, the use of import services in PMSE is subject to VAT in Indonesia because it is enjoyed or utilized in Indonesia.

The limitations on the collection of Value Added Tax are describing in the Regulation of the Director-General of Taxation No. PER-12/PJ/2020. The actual explained that the criteria limit for PMSE businesses for VAT collection are:

1. The value of transactions with buyers in Indonesia exceeds Rp.600.000.000,- in 1 year or Rp. 50.000.000,- in 1 month; and or

2. The amount of traffic or access in Indonesia exceeds 12,000 in 1 year or 1,000 in 1 month.

Suppose the PMSE business person has met the above criteria but has not been appointing as a VAT collector. In that case, the business actor can give notice independently to the DGT to obtain an appointment. Following Article 5 paragraph 2 PER-12/PJ/2020, notifications can be delivered by email address(email)or through the application or system specified and or provided by DGT. The business actor gives the notice can considering for DGT to appoint PMSE businesses as PMSE VAT collectors. 


\section{Writing Method}

This writing supporting data and information is collected by performing library searches, searching for relevant sources, and searching data over the Internet. The data and information used are electronic media data, taxation rules, and previous research. The data collection techniques are:

1. Tracking tax rules related to VAT PMSE

2. Conduct reference searches in the form of articles in electronic media to support discussion and analysis

\section{Discussion}

Directorate General of Taxes (DGT) stated that the implementation of value-added tax (PPN) collection through electronic trading (PMSE) is the first step, and there are still challenges that must be answered or anticipated. The VAT collection process in PMSE is still not optimal if you look at comparisons with other countries. The number of overseas companies designated as PMSE VAT collectors in Indonesia until the end of 2020 amounted to 46 companies in five waves of appointments. The number of businesses that collected VAT PMSE is still very minimal compared to other countries. For example, Australia has set approximately 560 companies since 2017.

Through the Directorate General of Taxation, the government revealed that there are at least three main challenges in implementing PMSE VAT collection in Indonesia. Some of the challenges facing the government are as follows:

1. DGT still has difficulty attracting overseas digital businesses to enter the tax administration system, exceptionally appointed as collectors and depositors of VAT PMSE.

2. Ensure tax compliance of foreign businesses that have been designing as collectors and depositors of VAT PMSE. A special rule is required to ensure compliance of the business

3. Ensure the role of PMSE VAT policy is aligned and supports PPh policy when global consensus in 2021 is reaching

Regulation of the Minister of Finance No. 48 of 2020 is the starting point of how tax authorities can capture the taxation of digital products abroad from the VAT side. Directorate General of Taxation will continue to communicate with other companies that sell digital products abroad to Indonesia. As for marketplaces that are domestic taxpayers who are designing as collectors, VAT collection is drive by the sale of digital goods and services by overseas sellers who sell through the marketplace. Following the comparative analysis of policies in several countries based on the Ottawa Framework Recommendation (OECD, 2003), the digital economy tax policy design should consider neutrality and fairness for PMSE businesses and conventional businesses. The increase in the potential of VAT PMSE in Indonesia hold if the government adds new provisions, among others, as follows:

1. Adding the scope of PMSE businesses, namely domestic traders and domestic service providers, either individuals or entities.

2. Adding PMSE tax object, i.e., taxable goods (BKP) intangible.

Based on the above discussions, the government should better monitor and evaluate the implementation of PMSE VAT running. In terms of regulation, new rules need to expand PMSE VAT objects expected to increase VAT receipts from the Electronic System Trade (PMSE) sector. The realization of value-added tax (VAT) receipts on digital products in electronic trading (PMSE) until the end of 2020 is Rp. 566.16 billion. With the expansion of the PMSE VAT tax base, it is expecting that state revenues in the PMSE VAT sector can increase from year to year.

\section{Conclusion}

Value Added Tax through Electronic System Trading (PMSE) is one of the promising tax potentials. Directorate General of Taxes (DGT) stated that the implementation of value-added tax (PPN) collection through electronic trading (PMSE) is the first step, and there are still challenges that must be answered or anticipated. Increasing the potential of VAT PMSE in Indonesia can be done by formulating new provisions, among others as follows: 
(a) Adding the scope of PMSE businesses, namely domestic traders and domestic service providers, either individuals or entities.

(b) Adding PMSE tax object, i.e. taxable goods (BKP) intangible.

By expanding the provision of potential VAT, PMSE is expecting to increase vat receipts from the Electronic System Trade (PMSE) sector, considering the contribution of VAT in state revenues is quite significant. The government must also evaluate and supervise the application of existing rules so that the number of businesses designated as PMSE VAT collectors can be increasing.

\section{List of Pustaka}

https://www.pajak.go.id/id/artikel/pmse-pajak-di-era-normal-baru

https://news.ddtc.co.id/masih-ada-tantangan-dalam-penerapan-ppn-pmse-ini-kata-djp--23462?page y=787.5

https://news.ddtc.co.id/index.php/6-perusahaan-sudah-ditunjuk-sebagai-pemungut-ppn-pmse-22058

https://www.pajak.go.id/id/siaran-pers/lagi-djp-tunjuk-10-perusahaan-pemungut-ppn-pmse

https://news.ddtc.co.id/apa-itu-pmse-dan-ppmse-19956

https://www.ortax.org/ortax/?mod=issue\&page=show\&id=114

https://news.ddtc.co.id/masih-ada-tantangan-dalam-penerapan-ppn-pmse-ini-kata-djp--23462?page_y=1608

https://workingpapers.bappenas.go.id/index.php/bwp/article/download/76/52

https://news.ddtc.co.id/penerimaan-ppn-produk-digital-pmse-tembus-setengah-triliun- 26061?page y=4.5

https://repository.ipb.ac.id/jspui/bitstream/123456789/19599/5/3 BAB\%20III\%20Metode\%20Write.pdf

https://www.pajak.go.id/sites/default/files/2020-09/SPPN-01\%20PPN\%20PMSE_Rev.1.pdf

https://peraturan.bpk.go.id/Home/Details/106025/pp-no-28-tahun-2019 